Techniques \& Culture

Revue semestrielle d'anthropologie des techniques

$34 \mid 2000$

Soieries médiévales

\title{
Sur la signification de "Diasprum"
}

\section{Donald King}

\section{(2) OpenEdition}

Journals

Édition électronique

URL : https://journals.openedition.org/tc/325

DOI : $10.4000 /$ tc. 325

ISSN : 1952-420X

Éditeur

Éditions de l'EHESS

Édition imprimée

Date de publication : 1 janvier 2000

ISSN : 0248-6016

Référence électronique

Donald King, "Sur la signification de "Diasprum" », Techniques \& Culture [En ligne], 34 | 2000, mis en ligne le 26 octobre 2005, consulté le 29 septembre 2022. URL : http://journals.openedition.org/tc/325 ; DOI : https://doi.org/10.4000/tc.325

Ce document a été généré automatiquement le 29 septembre 2022

Tous droits réservés 


\section{Sur la signification de "Diasprum"}

Donald King 